\title{
Peat swamp forest supports high primate densities on Siberut Island, Sumatra, Indonesia
}

\author{
Marcel C. Quinten, Matthias Waltert, Fauzan Syamsuri and \\ J. KEITH HODGES
}

\begin{abstract}
Although South-east Asia harbours most of the world's tropical peatlands relatively little is known about the primate communities of the associated habitat, the peat swamp forest. To understand better the role of tropical peat swamp forests for the conservation of primates in general, and for the endemic primates of the Mentawai Islands in particular, we conducted a line transect survey in a $12.5-\mathrm{km}^{2}$ section of peat swamp forest in northern Siberut. A total of 215 records of all four Siberut primates (Endangered Kloss's gibbon Hylobates klossii, Endangered Mentawai langur Presbytis potenziani, Vulnerable Siberut macaque Macaca siberu and Critically Endangered pig-tailed langur Simias concolor) were obtained. Pig-tailed langurs $\left(65.5 \mathrm{~km}^{-2}, 95 \%\right.$ confidence interval, CI, 41.9-102.6) and Siberut macaques $\left(35.8 \mathrm{~km}^{-2}, 95 \%\right.$ CI 25.5-50.4) were the most common species, with density estimates similar to (pig-tailed langur) or greater than (Siberut macaque) those in adjacent lowland rainforest on mineral soil. Density estimates of the Mentawai langur $\left(2.7 \mathrm{~km}^{-2}, 95 \% \mathrm{CI}\right.$ 1.3-5.3) and Kloss's gibbon $\left(1.0 \mathrm{~km}^{-2}, 95 \%\right.$ CI $\left.0.3-2.8\right)$ were approximately one-third and one-tenth, respectively, of the adjacent lowland rainforest. Given that resource density and diversity in peat swamp forest are probably lower than that of lowland rainforest, primate densities appear to be relatively high, with overall primate biomass $\left(881 \mathrm{~kg} \mathrm{~km}^{-2}\right)$ exceeding values for lowland rainforest on mineral soil. Our results underline the general importance that peat swamp forests may have for South-east Asian primates and for two island endemic species in particular.
\end{abstract}

Keywords Hylobates klossii, line transect survey, Macaca siberu, peat swamp forest, population density, Presbytis potenziani, Siberut, Simias concolor

This paper contains supplementary material that can be found online at http://journals.cambridge.org

Marcel C. Quinten* (Corresponding author) and Matthias Waltert Department of Conservation Biology, Centre for Nature Conservation, Georg-August-Universität Goettingen, Von-Siebold Str. 2, 37075 Goettingen, Germany. E-mail marcel.quinten-dpz@gmx.de

Fauzan Syamsuri Siberut Conservation Programme, Pondok, Padang, Indonesia.

J. KeIth Hodges Department of Reproductive Biology, German Primate Center, Goettingen, Germany.

${ }^{*}$ Also at: Department of Reproductive Biology, German Primate Center, Kellnerweg 4, 37077 Goettingen, Germany.

Received 20 November 2008. Revision requested 27 January 2009. Accepted 11 April 2009.

\section{Introduction}

7 ropical lowland rainforest on mineral soil is one of the 1 most important habitats for South-east Asian primates and, consequently, its loss as a result of logging and agricultural conversion (Achard et al., 2002) is the principal threat to the survival of many primate species in this region. As the extent of lowland rainforest on mineral soil progressively declines, forest types less affected by anthropogenic exploitation gain additional importance as primate habitat. Peatlands, which cover substantial parts of the tropics (c. 400,000 $\mathrm{km}^{2}$; Page et al., 2008), are especially abundant in South-east Asia, and many regional primate species are known to occur regularly in peat swamp forest habitat (Wolfheim, 1983; Page et al., 1997; Gupta \& Chivers, 1999). Detailed information on primate population sizes in this forest type, however, is available only for the orangutan Pongo spp. and the agile gibbon Hylobates agilis (Buckley et al., 2006; Wich et al., 2008). In particular, little is known about primate communities in the peat swamps of the many small islands (but see Felton et al., 2003).

This article presents the results of a primate survey carried out in a peat swamp forest on Siberut, one of the four main Mentawai Islands off the west coast of Sumatra, Indonesia. The Mentawai Islands, like most areas within the Sundaland region, have lost large tracts of their original lowland rainforest on mineral soil (Whittaker, 2006), and much of the remaining forest habitat continues to be threatened by logging and agricultural expansion. In contrast, peat swamp forest has remained largely intact and currently accounts for up to $5 \%$ of the islands' ecosystems. The peat swamp forest surveyed here forms part of a c. 5,500-ha area of relatively undisturbed rainforest (the Peleonan forest) under the protection of the Siberut Conservation Programme. Our earlier survey in lowland rainforest on mineral soil in the Peleonan forest (Waltert et al., 2008) indicated unusually high densities of all four endemic primate species: the Endangered Kloss's gibbon Hylobates klossii, Vulnerable Siberut macaque Macaca siberu, Endangered Mentawai langur Presbytis potenziani and Critically Endangered pig-tailed langur Simias concolor (IUCN, 2009). By providing population estimates for the peat swamp forest component of the Peleonan forest and comparing these findings with those from the adjacent lowland rainforest on mineral soil, our aims are to assess the potential value of peat swamp forest as habitat for Siberut primates and to contribute to knowledge of the 
conservation significance of this habitat for South-east Asian primates in general.

\section{Study area}

The peat swamp forest chosen for our survey (Fig. 1) forms the northern part of the Peleonan forest. Mean daily temperatures are $22-31^{\circ} \mathrm{C}$, humidity $80-95 \%$, and mean annual total precipitation is $4,200 \mathrm{~mm}$; there is no distinct dry season (WWF, 1980; Whitten, 1982). Confined by the ocean to the north, the river Sigep in the east and the river Peleonan in the west, the peat swamp forest gives way to lowland rainforest on mineral soil in the south, c. $2.5-3.5 \mathrm{~km}$ from the shoreline, and its borders encompass a total area of c. $12.5 \mathrm{~km}^{2}$ (Fig. 1). Forest structural data, collected throughout the study, are provided in Table 1 and a list of 42 tree species, collected by opportunistic sampling, in the Appendix. Based on these data and information from local people, we estimate that the area of peat swamp forest studied holds $65-75$ tree species.

\section{Methods}

The primate survey followed a standard line transect sampling approach (Buckland et al., 2001) using a system of 10 1-m wide permanent transects (BT 01-10), each branching off at a $90^{\circ}$ angle from a main transect path of $2 \mathrm{~km}$ length. Five transects (BT 01, 03, 05, 07 and 09) were cut westward and five (BT 02, 04, 06, 08 and 10) eastward in an alternating fashion. All branches on each side were placed $400 \mathrm{~m}$ apart and cut to an equal length of $1.2 \mathrm{~km}$. The entire system covers an area of c. $4.7 \mathrm{~km}^{2}$ (Fig. 1).

We surveyed from 1 August to 27 September 2007, with a survey team consisting of two Mentawaians and MCQ.
Assistants were familiarized with the methodology, census protocol (Peres, 1999; Waltert et al., 2002) and equipment. We conducted surveys at 7.00-9.00, 9.30-11.30 and 15.30-17.30. For each observation, time, location (with a global positioning system), primate species, number of individuals, group composition (if identifiable) and perpendicular distance (with a laser range finder) from the transect line to the centre of all measurable individuals of each primate cluster were recorded. When primates were only detected acoustically, the perpendicular distance was measured to the estimated location. Overall survey effort was calculated as the sum of all distances walked without disturbance by rain or earthquakes. Transects were walked up to five times, giving a total survey effort of $51.6 \mathrm{~km}$.

Distance v. 4.1 (Thomas et al., 2004) was used to analyse data from both visual and acoustic encounters. Data were truncated for estimating the detection function $(g(x))$ and independently for estimation of cluster size so that the expected cluster size $\left(E_{s}\right)$ incorporated only observations near to the transect (Table 2). $E_{s}$ was determined using the size bias regression method, regressing $\ln$ (cluster size) against the estimated $g(x)$ (Thomas et al., 2004). Density estimates were used to calculate primate biomass density, based on average weights of Mentawai primates given by Rowe (1996): $7.9 \mathrm{~kg}$ (S. concolor), $9.5 \mathrm{~kg}$ (M. siberu), $6.5 \mathrm{~kg}$ (P. potenziani) and $5.8 \mathrm{~kg}$ (H. klossii). Comparisons of local primate density in peat swamp forest and lowland rainforest on mineral soil were made using $\hat{D}_{\mathrm{PSF}}$ (density estimate from the present study in the peat swamp) and $\hat{D}_{\mathrm{LRM}}$ (density estimate for lowland rainforest on mineral soil from Waltert et al., 2008), using $z$ statistics ( $\mathrm{df}>30$; see Buckland et al., 2001), testing the null hypothesis $H_{\mathrm{o}}: D_{\mathrm{PSF}}=D_{\mathrm{LRM}}$.

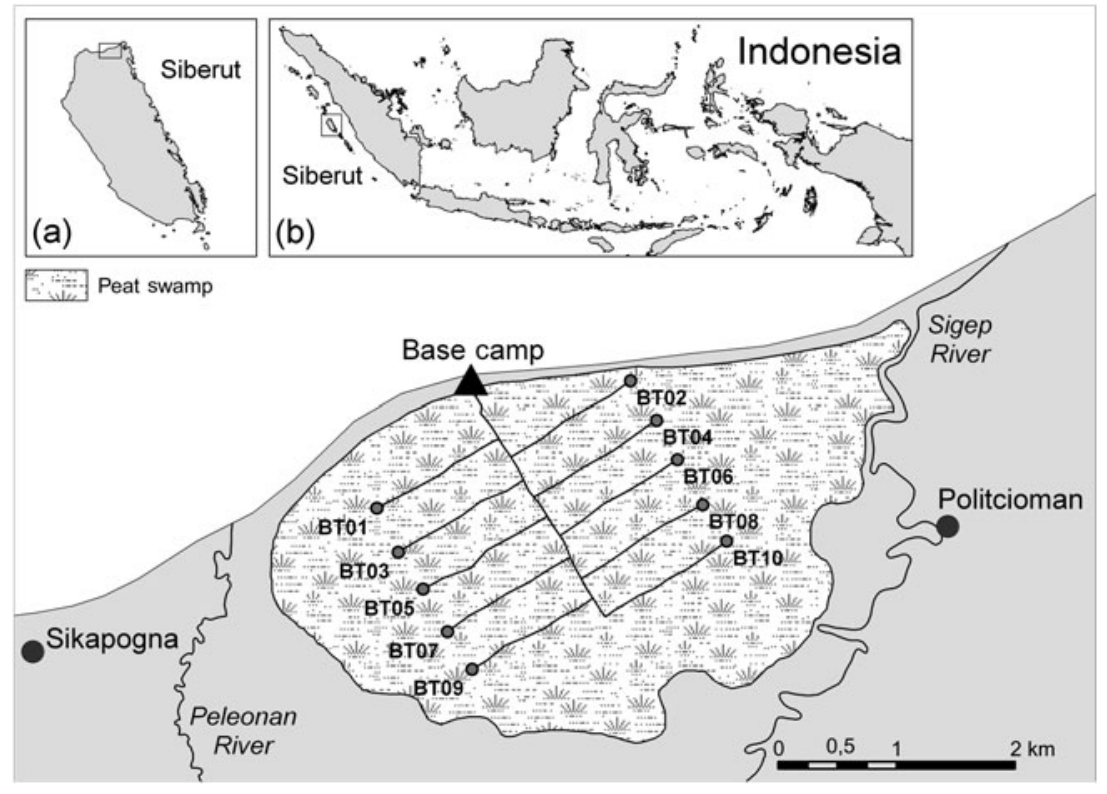

FIG. 1 Location of the study area in the peat swamp forest of Siberut, with the layout of the transect system (BT01-10, see text for further details) shown. The rectangles on the insets indicate the location of the study area in northern Siberut (a) and of Siberut in Sumatra, Indonesia (b). 
TABle 1 Semi-quantitative description of the peat swamp forest within the $12.5 \mathrm{~km}^{2}$ study area in the Pelonean forest (Fig. 1). The most common tree families are Lauraceae, Myrtaceae and Myristicaceae (see also Appendix).

\begin{tabular}{llll}
\hline Feature & $\mathrm{n}$ & Range & Mean \\
\hline General peat depth $(\mathrm{m})$ & 40 & & $>2.30$ \\
Basal area of trees $\left(\mathrm{m}^{2} \mathrm{ha}^{-1}\right)$ & 10 & $17-35$ & 26.8 \\
Tree height $(\mathrm{m})$ & 60 & $4.5-34$ & 16.3 \\
DBH $(\mathrm{cm})$ & 60 & $10.3-86.6$ & 24.9 \\
\hline
\end{tabular}

\section{Results}

Of a total of 215 detection events, $S$. concolor was encountered 82 times, $M$. siberu 99 times and both P. potenziani and $H$. klossii 17 times. The number of observations available for analysis after data truncation are given in Table 2.

Average cluster sizes of the four species ranged from 1.5 (P. potenziani) to 3.2 (H. klossii) individuals. S. concolor was the most abundant species and our estimates show that $520-1,270$ individuals $\left(65.5 \mathrm{~km}^{-2}\right)$, with an overall biomass of $518 \mathrm{~kg} \mathrm{~km}^{-2}$, live in the study area. The second most abundant primate was $M$. siberu, with an estimated 316-625 individuals $\left(35.8 \mathrm{~km}^{-2}\right)$ and a biomass of $341 \mathrm{~kg} \mathrm{~km}^{-2}$. We encountered relatively few $P$. potenziani and $H$. klossii and estimate that 16-66 P. potenziani, at a density of $2.7 \mathrm{~km}^{-2}$, and 4-35 H. klossii, at a density of c. $1 \mathrm{~km}^{-2}$, live in the study area (Table 2).

Our density estimate for $S$. concolor does not differ significantly from that obtained previously for lowland rainforest on mineral soil (Fig. 2; Waltert et al., 2008; $z=0.74$, $\mathrm{P}=0.46$ ) but that of $M$. siberu is nearly twice as high in the peat swamp forest as in the lowland rainforest on mineral soil $(z=2.59, \mathrm{P}=0.0097)$. Densities of $P$. potenziani were approximately one-third $(z=-2.31, \mathrm{P}=0.0207)$ and of H. klossii $(z=-3.91, \mathrm{P}=0.0001)$ one-tenth those of the same species in lowland rainforest on mineral soil.

\section{Discussion}

This study is the first attempt to determine density and population sizes of primates in Siberut's peat swamp forests, and the results confirm that all four endemic primate species use this habitat. M. siberu occurs in the peat swamp forest at approximately twice the density of the adjacent lowland rainforest on mineral soil (Waltert et al., 2008). As mean cluster sizes are similar in both forest types it appears there is habitat-related variation in group density. The relatively high density in a habitat with lower diversity of resources (Whitten \& Whitten, 1982) and trees (Hadi et al., 2009; peat swamp forest: c. 70 genera; lowland rainforest on mineral soil: 139 genera), lower canopy height and patchy forest structure is surprising. However, trees in peat swamp forests have been reported not to mast (Cannon et al., 2007) and this may result in fruit being more continuously available, thereby representing a more reliable food source compared to lowland rainforest on mineral soil.

The finding that $H$. klossii use the peat swamp forest was also unexpected. Although the species has been reported in this forest type, it is considered a marginal habitat for the species (Whitten, 1982), and because gibbons are totally arboreal, the forest structure associated with the low basal area of trees in Siberut's peat swamp forests must make movement relatively difficult. Our transect data suggest that at least three to four groups of H. klossii (c. 12 individuals) may be permanently resident in the peat swamp forest. This is supported by observations on three separate occasions when gibbon calls were simultaneously heard from three

TABLE 2 Mean encounter rate, size and density of primate clusters and detection probability (with 95\% confidence intervals, CI), truncation distances for cluster size $(c)$ and density $(w)$ estimation, number of clusters encountered $(\mathrm{n})$, mean density estimate of individuals (with 95\% CI and coefficient of variation, CV), and estimates of biomass density and population size and range (based on 95\% CI of mean density of individuals) of the four primate species of the peat swamp forest of northern Siberut (Fig. 1).

\begin{tabular}{|c|c|c|c|c|}
\hline & $\begin{array}{l}\text { Pig-tailed langur } \\
\text { Simias concolor }\end{array}$ & $\begin{array}{l}\text { Siberut macaque } \\
\text { Macaca siberu }\end{array}$ & $\begin{array}{l}\text { Mentawai langur } \\
\text { Presbytis potenziani }\end{array}$ & $\begin{array}{l}\text { Kloss's gibbon } \\
\text { Hylobates klossii }\end{array}$ \\
\hline $\begin{array}{l}\text { Mean encounter rate of } \\
\text { clusters, } \mathrm{km}^{-1}(95 \% \mathrm{CI})\end{array}$ & $1.57(1.06-2.33)$ & $1.72(1.35-2.20)$ & $0.25(0.17-0.38)$ & $0.31(0.12-0.78)$ \\
\hline Mean cluster size $(95 \% \mathrm{CI})$ & $3.1(2.6-3.8)$ & $2.6(2.0-3.3)$ & $1.5(1.1-2.1)$ & $3.2(1.3-7.6)$ \\
\hline $\begin{array}{l}\text { Mean cluster density, } \mathrm{km}^{-2} \\
\quad(95 \% \mathrm{CI})\end{array}$ & $21.1(13.9-32.0)$ & $13.9(10.7-18.0)$ & $1.8(0.9-0.4)$ & $0.3(0.1-0.8)$ \\
\hline Detection probability $(95 \% \mathrm{CI})$ & $0.50(0.42-0.59)$ & $0.68(0.61-0.77)$ & $0.72(0.41-1.00)$ & $0.81(0.47-1.00)$ \\
\hline$c(\mathrm{~m})$ & 33 & 28 & 35 & 125 \\
\hline$w(\mathrm{~m})$ & 75 & 99 & 91 & 620 \\
\hline $\mathrm{n}$ & 81 & 89 & 13 & 16 \\
\hline $\begin{array}{l}\text { Mean density, individuals } \mathrm{km}^{-2} \\
\quad(95 \% \mathrm{CI}, \mathrm{CV})\end{array}$ & $65.5(41.9-102.6,21.8)$ & $35.8(25.5-50.4,17.0)$ & $2.7(1.3-5.3,34.7)$ & $0.98(0.34-2.8,53.9)$ \\
\hline Biomass density $\left(\mathrm{kg} \mathrm{km}^{-2}\right)$ & 517.7 & 340.5 & 17.2 & 5.7 \\
\hline Population size (range) & $813(519-1,272)$ & $444(316-625)$ & $33(16-66)$ & $12(4-35)$ \\
\hline
\end{tabular}




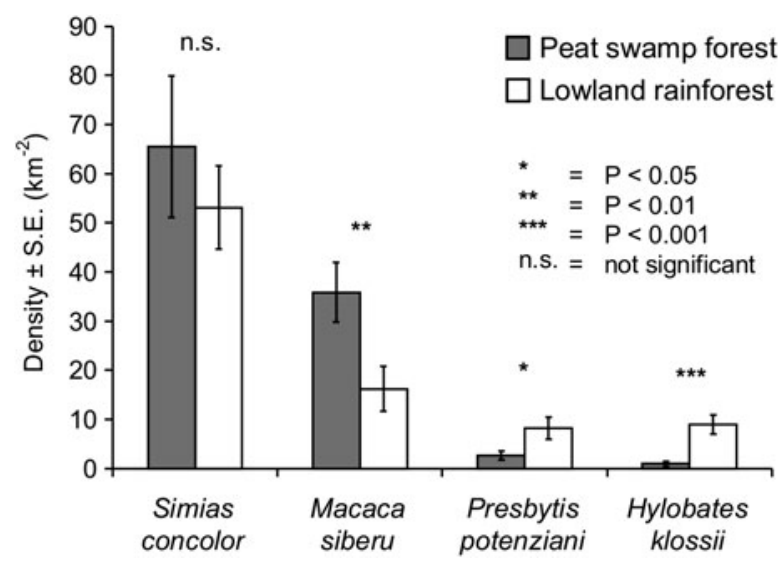

FIG. 2 Comparison of individual primate densities in peat swamp forest (this study) and lowland rainforest on mineral soil (Waltert et al., 2008).

different groups within the study area. Assuming that home ranges are approximately circular with a size of 31-35 ha (Whitten, 1982), ranges of all visually detected gibbon groups would fall entirely within the boundary of the peat swamp forest studied.

The lower densities of $P$. potenziani compared to the lowland rainforest on mineral soil may be because of the different compositions and ecology of the respective forest types. In primary forests $P$. potenziani feed mainly on climbers and trees of the Dipterocarpaceae, which are not abundant in the peat swamp forest of the Pelonean forest, and the species' most common resting sites are large emergents or upper canopy trees with heavy climber cover, trees that are not abundant in the peat swamp forest (Fuentes, 1996). Consequently, this habitat may be less suitable for the species compared to lowland rainforest on mineral soil.

In contrast, $S$. concolor was found in densities comparable to those in lowland rainforest on mineral soil (Waltert et al., 2008), a finding in accordance with those of Watanabe (1981), Tenaza (1989) and S. Hadi (pers. comm.), who described $S$. concolor to be adaptable to different habitat types provided local disturbance levels are low. Where disturbance from logging and hunting in the archipelago is highest (e.g. on the Pagai Islands or southern Siberut), S. concolor densities are lower (Tenaza \& Fuentes, 1995; Paciulli, 2004) than in less disturbed areas, such as northern Siberut (Watanabe, 1981). The high population densities in the north underscore the conservation importance of the region for this Critically Endangered species and emphasize the urgent need for effective conservation measures, especially in view of the continuing threats to the area posed by commercial logging (a 35,000-ha logging concession spans almost the entire north of Siberut with the exception of the Peleonan forest; R. Soekmadi, pers. comm.).

Because access to and local settlement within forests on tropical peatland have been relatively difficult, they have generally not been intensively used. However, as new technologies facilitate access to these areas, peat swamp forests are becoming targets for commercial exploitation. Although anthropogenic influence on peat swamp forest on Siberut has so far been limited, pressures are almost certain to increase and currently none of the island's peat forest is protected. In addition to a range of important ecological services that peat swamp forests provide (e.g. water storage and supply, erosion prevention, flood mitigation, carbon storage; Sorensen, 1993; Rieley \& Page, 2005), our results indicate their potential value on Siberut as habitat for the island's four endemic primates. As such, we believe that effective conservation of peat swamp forest in this region is urgently required.

We propose a three-fold approach towards achieving this. Firstly, further surveys in other peat swamp forest locations within the archipelago need to be conducted and more detailed information on the extent and distribution of peat swamp forest acquired; these activities are planned as part of Siberut Conservation Programme's future work in the region. Secondly, the importance of peat swamp forest as a habitat for primates requiring protection should be emphasized to both regional (Mentawai District Government) and national (Directorate General of Forest Protection and Nature Conservation (PHKA), Indonesian Ministry of Forestry) authorities to limit any future escalation in logging and other forms of exploitation of this relatively undisturbed habitat. Thirdly, the potential economic value of the region's peat swamp forests as carbon storage sinks needs to be quantitatively assessed, and ways to achieve their accreditation under current $\mathrm{CO}_{2}$ emission reduction schemes actively sought.

\section{Acknowledgements}

We thank the German Primate Center for funding the research, the Siberut Conservation Programme and Bogor Agricultural University for valuable advice and support, the staff of the Herbarium Bogoriense for the identification of tree material, local guides Pak Gerson, Pak Piator and Pak Sabar, and Dodi Priata, Yulia Handayani, Dr Jack Rieley and Simone Scherer.

\section{References}

Achard, F., Eva, H.D., Stibig, H.J., Mayaux, P., Gallego, J., Richards, T. \& Malingreau, J.P. (2002) Determination of deforestation rates of the world's humid tropical forests. Science, 297, 999-1002.

Buckland, S.T., Anderson, D.R., Burnham, K.P., Laake, J.L, Borchers, D.L. \& Thomas, L. (2001) Introduction to Distance Sampling: Estimating Abundance of Biological Populations. Oxford University Press, New York, USA.

Buckley, C., Nekaris, K.A.I. \& Husson, S.J. (2006) Survey of Hylobates agilis albibarbis in a logged peat-swamp forest: Sabangau catchment, Central Kalimantan. Primates, 47, 327-335. 
Cannon, C.H., Curran, L.M., Marshall, A.J. \& Leighton, M. (2007) Beyond mast-fruiting events: community asynchrony and individual dormancy dominate woody plant reproductive behaviour across seven Bornean forest types. Current Science, 93, $1558-1566$.

Felton, A.M., Engstrom, L.M. \& Felton, A. \& Knott, C.D. (2003) Orang-utan population density, forest structure and fruit availability in hand-logged and unlogged peat swamp forests in West Kalimantan, Indonesia. Biological Conservation, 114, 91-101.

Fuentes, A. (1996) Feeding and ranging in the Mentawai Island langur (Presbytis potenziani). International Journal of Primatology, $17,525-548$.

Gupta, A.K. \& Chivers, D.J. (1999) Biomass and use of resources in south and south-east Asian primate communities. In Primate Communities (eds J.G. Fleagle, C. Janson \& K.E. Reed), pp. 38-54. Cambridge University Press, Cambridge, UK.

Hadi, S., Ziegler, T., Waltert, M. \& Hodges, J.K. (2009) Tree diversity and forest structure in northern Siberut, Mentawai islands, Indonesia. Tropical Ecology, 50, 315-327.

IUCN (2009) IUCN Red List of Threatened Species v. 2009.1. Http:// www.iucnredlist.org [accessed 15 September 2009].

PaCiUlli, L.M. (2004) The effects of logging, hunting, and vegetation on the densities of the Pagai, Mentawai Island primates. PhD thesis, State University of New York, New York, USA.

Page, S.E., Banks, C.J., Rieley, J.O. \& Wüst, R. (2008) Extent, significance and vulnerability of the tropical peatland carbon pool: past, present and future prospects. In Proceedings of the 13th International Peat Congress: After Wise Use-The Future of Peatlands (eds C. Farrell \& J. Feehan), pp. 233-236. International Peat Society, Tullamore, Ireland.

Page, S.E., Rieley, J.O., Doody, K., Hodgson, S., Husson, S., Jenkins, P.M. et al. (1997) Biodiversity of tropical peat swamp forest: a case study of animal diversity in the Sungai Sebangau catchment in Central Kalimantan. In Biodiversity and Sustainability of Tropical Peatlands (eds J.O. Rieley \& S.E. Page), pp. 231-242. Samara Publishing, Cardigan, UK.

Peres, C.A. (1999) General guidelines for standardizing line-transect surveys of tropical forest primates. Neotropical Primates, 7, 11-16.

Rieley, J.O. \& Page, S.E. (2005) Wise Use of Tropical Peatlands: Focus on South-east Asia. ALTERRA, Wageningen University and Research Centre, and the EU INCO, STRAPEAT and RESTORPEAT Partnerships, Wageningen, The Netherlands.

Rowe, N. (1996) The Pictorial Guide to the Living Primates. Pogonias Press, New York, USA.

Sorensen, K.W. (1993) Indonesian peat swamp forests and their role as a carbon sink. Chemosphere, 27, 1065-1082.

TenazA, R.R. (1989) Intergroup calls of male pig-tailed langurs (Simias concolor). Primates, 30, 199-206.

Tenaza, R.R. \& Fuentes, A. (1995) Monandrous social organization of pigtailed langurs (Simias concolor) in the Pagai Islands, Indonesia. International Journal of Primatology, 16, 295-310.
Thomas, L., Laake, J.L., Strindberg, S., Marques, F.F.C., Buckland, S.T., Borchers, D.L. et al. (2004) Distance 4.1. Release 2. Research Unit for Wildlife Population Assessment, University of St. Andrews, St. Andrews, UK. Http://www.ruwpa. st-and.ac.uk/distance/ [accessed 8 July 2008].

Waltert, M., Abegg, C., Ziegler, T., Hadi, S., Priata, D. \& Hodges, K. (2008) Abundance and community structure of Mentawai primates in the Peleonan forest, North Siberut, Indonesia. Oryx, 42, 375-379.

Waltert, M., Lien, Faber, K. \& Mühlenberg, M. (2002) Further declines of threatened primates in the Korup Project Area, south-west Cameroon. Oryx, 36, 257-265.

Watanabe, K. (1981) Variations in group composition and population density of two sympatric Mentawaian leaf-monkeys. Primates, 22, 145-160.

Whittaker, D.J. (2006) A conservation action plan for the Mentawai primates. Primate Conservation, 20, 95-105.

Whitten, A.J. (1982) A numerical analysis of tropical rainforest using floristic and structural data and its application to an analysis of gibbon ranging behaviour. Journal of Ecology, 70, 249-271.

Whitten, A.J. \& Whitten, J.E.J. (1982) Preliminary observations of the Mentawai macaque on Siberut Island, Indonesia. International Journal of Primatology, 3, 445-459.

Wich, S.A., Meijaard, E., Marshall, A.J., Husson, S., Ancrenaz, M., Lacy, R.C. et al. (2008) Distribution and conservation status of the orang-utan (Pongo spp.) on Borneo and Sumatra: how many remain? Oryx, 42, 329-339.

Wolfheim, J.H. (ed.) (1983) Primates of the World: Distribution, Abundance and Conservation. University of Washington Press, Seattle, USA.

WWF (1980) Saving Siberut: A Conservation Master Plan. WWF Indonesia Programme, Bogor, Indonesia.

\section{Appendix}

The appendix for this article is available online at http:// journals.cambridge.org

\section{Biographical sketches}

Marcel C. Quinten is a conservation biologist working together with the German Primate Center and the Siberut Conservation Programme on the preservation of the endemic primates of the Mentawai archipelago. Matthias Waltert studies the effects of forest land use on tropical biodiversity and teaches wildlife population and biodiversity assessment in the integrated bi-national MSc International Nature Conservation at Georg-August-Universitaet Goettingen, Germany, and Lincoln University, New Zealand. FauzaN SYAMSURI is concerned with tropical forest management and is the field station manager of the Siberut Conservation Programme on Siberut Island. J. Keith Hodges has research interests in evolutionary endocrinology and comparative reproduction in primates. 